\title{
Comparison of career decision difficulties between nursing freshmen and interns
}

\author{
Ni Putu Wulan Purnama Sari ${ }^{1}$, Made Mahaguna Putra ${ }^{2}$ \\ ${ }^{1}$ Department of Palliative Nursing, Faculty of Nursing, Widya Mandala Catholic University Surabaya, Indonesia \\ ${ }^{2}$ Department of Nursing, STIKES Buleleng, Indonesia
}

\begin{abstract}
Article Info
Article history:

Received Jul 8, 2019

Revised Aug 8, 2019

Accepted Aug 27, 2019

\section{Keywords:}

Career decision difficulties

Career decision-making

Nursing freshmen

Nursing interns

Nursing student

ABSTRACT

Career selection is one of the most important decisions an individual makes in his life. High career expectation could result in career decision difficulties. This study aimed to compare and analyze the career decision difficulties between nursing freshmen and interns. This cross-sectional study involved 110 and 66 nursing freshmen and interns respectively $(n=176)$ in two private nursing colleges. Career decision difficulties questionnaire was used in data collection. Descriptive statistic and independent sample $t$ test were used in data analysis $(\alpha<.05)$. Results showed that most respondents experienced moderate difficulties in both groups. Overall, there was no significant difference of career decision difficulty found between groups $(\mathrm{p}=.057)$, but indecisiveness, dysfunctional myths, lack of knowledge about the process of career decision making, lack of information, lack of information about occupations, lack of information about ways of obtaining additional information, and internal conflicts were significantly different between groups $($ all $\mathrm{p}<\alpha$ ). Career decision difficulties occur similarly both in nursing freshmen and interns.
\end{abstract}

Copyright $(9) 2019$ Institute of Advanced Engineering and Science. All rights reserved.

\section{Corresponding Author:}

Ni Putu Wulan Purnama Sari,

Department of Palliative Nursing, Faculty of Nursing,

Widya Mandala Catholic University Surabaya,

Jl. Raya Kalisari Selatan 1, Pakuwon City, Surabaya 60112, Indonesia.

Email: wulanpurnama@ukwms.ac.id

\section{INTRODUCTION}

Betz stated that career decision making is vital in career development [1]; and related to career expectation. Parsons explains that career decision making process is an individual process of understanding himself and the world of work which lead to the integration of both understandings resulted in career determination [1]. High career expectations have the potential to cause difficulties in deciding a career, so that individuals are increasingly hesitant to make career choices. According to Slaney, career decision difficulty means problems encountered by individuals in deciding their careers [2].

Several theoretical approaches have been used to explain the causes of difficulties in deciding a career with emphasis on different aspects. Bordin \& Kopplin suggested a psychodynamic theory which stated that individual problems can be calcified based on internal resources rather than visible symptoms [2]. Another theorist, Crites, suggested a development theory which stated that the problem arises normally because it relates to the stages of individual career development, with an emphasis on the concept of vocational maturity [2]. Some other theorists, such as Holland, Roe, and Salomone, suggested a theory of vocational attraction/interest which stated that problems occur due to a lack of crystallization of interest (major factor) that prevents individuals from making decisions [2]. Based on the various theories above, Gati, et al., developed the concept of career decision difficulties [2]. Career decision difficulties include several dimensions, such as: lack of readiness, indecisiveness, dysfunctional myths, lack of knowledge about the 
process of career decision making; lack of information about self, occupations, and ways of obtaining additional information; unreliable information, internal and external conflicts [2].

Based on a study towards 304 students in America, it is known that problems arise in two periods of time, namely at the beginning of the learning process in the college, and during the process of studying in the college. Problems that occur in the initial phase include a lack of individual readiness, which is described as four main problems, namely: 1) lack of motivation, 2) presents of doubts, 3) the existence of dysfunctional myths circulating in the community, and 4) lack of knowledge about the learning process in the college. While the problems that occur during the study process phase include two main categories, namely: 1) lack of information about self, the work in question, and how to get the right information, and 2) information inconsistencies due to improper information, and the existence of conflict (internal and external) [2].

This study aimed to compare and analyze the career decision difficulties between nursing freshmen and interns. In Indonesia, the nursing education in Bachelor degree is divided into two phases. The first phase is 4-years academic degree of nursing, and the second phase is 1-year nurse professional degree which fully conducted in clinical setting; therefore the student nurse in this phase is called "intern".

\section{RESEARCH METHOD}

This cross-sectional study involved 110 and 66 nursing freshmen and interns respectively in two private nursing colleges in the middle part of Indonesia, both institutions were "B" accredited. Inclusion criteria were at least 16 years old and being an active student in the commencement of even semester, academic year of 2018/2019. Exclusion criteria were rejection on filling out the consent form, and late submission of questionnaire. Total sampling was applied and sample size of 176 was obtained. Data were collected since February until March, 2019, in both sites. Ethical clearance was issued by Faculty of Medicine, Widya Mandala Catholic University Surabaya, Indonesia, with certificate number of 009/WM12/KEPK/T/2019.

Gati, et al. [2] developed the career decision difficulties questionnaire [2]. This instrument initially consisted of 44 statements covering nine domains, namely: 1) lack of readiness, 2) indecisiveness, 3) dysfunctional myths, 4) lack of knowledge about the process of career decision making, 5) lack of information about self, 6) lack of information about occupations, 7) lack of ways of obtaining additional information, 8) unreliable information, 9) internal and external conflicts. The answer choice consists of nine alternatives in a particular response range, starting from "does not describe me" (score 1) to "describes me well" (score 9). The results of instrument testing procedure towards 25 nursing students showed that there were 42 valid items ( $\mathrm{r}=.402-.867)$ and have high reliability (Chronbach Alpha=.978). Item 2 about perception of work as the most important thing in life and item 39 about abilities are insufficient for the requirements of the preferred career alternative were proved to be invalid, so they were removed from the instrument. At the end of the questionnaire, respondents were asked to assess the severity of the difficulties experienced ( $1=$ not at all until $9=$ very severe) and write additional barriers that could prevent them from making career decisions (qualitatively assessed). The maximum value that can be obtained is 378 , while the minimum value is 42 . To ease the data presentation in the result section, career decision difficulties were divided into three categories, namely: 1) mild difficulties (total score 42-154), 2) moderate difficulties (total score 155-266), and 3) severe difficulties (total score 267-378). The data distribution of career decision difficulty was normal $(\alpha=.307)$. Descriptive statistic and independent sample $t$ test were used for analyzing the data $(\alpha<.05)$.

\section{RESULTS AND DISCUSSIONS}

Most respondents were single females aged 18-20 years old, Balinese, and living with parents whose profession was non-nursing. Most interns were older than freshmen. Some interns even experienced marriage life during their study period. Table 1 explains demographic characteristic of respondents in details.

The results of descriptive statistic showed that the Mean of career decision difficulty was higher in nursing freshmen compared to interns, and the data was more homogenous due to lower SD (Mean=191.32 vs. 174.39 , SD: 43.38 vs. 74.06). The results of independent sample t test showed that overall there was no significant difference of career decision difficulty found between nursing freshmen and interns $(\mathrm{p}=.057)$. But, the results of deeper analysis towards each item of career decision difficulties questionnaire showed that there were significant differences found between groups in 14 items. The domain of "lack of information" seemed to be the key of these significant differences, as four items were affected. Table 2 explains the significant differences between groups in details. 
Table 1. Demographic characteristic

\begin{tabular}{|c|c|c|c|c|}
\hline \multirow{2}{*}{ Characteristic } & \multicolumn{2}{|c|}{ Freshmen $(n=110)$} & \multicolumn{2}{|c|}{ Intern $(n=66)$} \\
\hline & Frequency & $\%$ & Frequency & $\%$ \\
\hline \multicolumn{5}{|l|}{ 1. Age (years old) } \\
\hline a. $16-17$ & 14 & 12.73 & 0 & 0 \\
\hline b. $18-20$ & 90 & 81.82 & 1 & 1.52 \\
\hline c. $21-23$ & 5 & 4.55 & 58 & 87.88 \\
\hline d. $24-26$ & 0 & 0 & 7 & 10.61 \\
\hline e. $>26$ & 1 & 0.91 & 0 & 0 \\
\hline \multicolumn{5}{|l|}{ 2. Gender } \\
\hline a. Female & 85 & 77.27 & 49 & 74.24 \\
\hline b. Male & 25 & 22.73 & 17 & 25.76 \\
\hline \multicolumn{5}{|l|}{ 3. Ethnic } \\
\hline a. Javanese & 18 & 16.36 & 10 & 15.15 \\
\hline b. Balinese & 58 & 52.73 & 47 & 71.21 \\
\hline c. Chinese & 2 & 1.82 & 1 & 1.52 \\
\hline d. NTT or east Indonesia & 18 & 16.36 & 5 & 7.58 \\
\hline e. Borneo & 3 & 2.73 & 0 & 0 \\
\hline f. Sulawesi & 0 & 0 & 2 & 3.03 \\
\hline g. Others & 11 & 10.00 & 1 & 1.52 \\
\hline \multicolumn{5}{|l|}{ 4. High school (HS) background } \\
\hline a. HS in Bali & 64 & 58.18 & 47 & 71.21 \\
\hline b. HS in East Java & 17 & 15.45 & 11 & 16.67 \\
\hline c. HS outside Java (RI) & 29 & 26.36 & 8 & 12.12 \\
\hline \multicolumn{5}{|l|}{ 5. Marital status } \\
\hline a. Single & 96 & 87.27 & 39 & 59.09 \\
\hline b. In a relationship & 14 & 12.73 & 23 & 34.85 \\
\hline c. Married & 0 & 0 & 3 & 4.55 \\
\hline d. Separated & 0 & 0 & 1 & 1.52 \\
\hline \multicolumn{5}{|l|}{ 6. Socioeconomic status } \\
\hline a. Middle & 83 & 75.45 & 53 & 80.30 \\
\hline b. Low middle & 25 & 22.73 & 8 & 12.12 \\
\hline c. Middle up & 2 & 1.82 & 5 & 7.58 \\
\hline \multicolumn{5}{|l|}{ 7. Living at home with } \\
\hline a. Parents & 59 & 53.64 & 52 & 78.79 \\
\hline b. Sibling & 4 & 3.64 & 2 & 3.03 \\
\hline c. Extended Family & 13 & 11.82 & 6 & 9.09 \\
\hline d. Friends & 30 & 27.27 & 5 & 7.58 \\
\hline e. Alone & 4 & 3.64 & 1 & 1.52 \\
\hline \multicolumn{5}{|l|}{ 8. Profession of house-mate } \\
\hline a. Nurse & 3 & 2.73 & 4 & 6.06 \\
\hline b. Doctor & 1 & 0.91 & 1 & 1.52 \\
\hline c. Pharmacist & 1 & 0.91 & 0 & 0 \\
\hline d. Others & 105 & 95.45 & 61 & 92.42 \\
\hline \multicolumn{5}{|l|}{ 9. Nurse is parent's profession } \\
\hline a. Yes & 6 & 5.45 & 4 & 6.06 \\
\hline b. No & 104 & 94.55 & 62 & 93.94 \\
\hline \multicolumn{5}{|l|}{ 10. Reason of choosing nursing major } \\
\hline a. Making family proud & 1 & 0.91 & 0 & 0 \\
\hline b. Being able to care the family & 9 & 8.18 & 6 & 9.09 \\
\hline c. Personal dream/preference & 54 & 49.09 & 13 & 19.70 \\
\hline d. Being able to help others & 32 & 29.09 & 14 & 21.21 \\
\hline e. Many job opportunities & 3 & 2.73 & 8 & 12.12 \\
\hline f. Others & 11 & 10.00 & 25 & 37.88 \\
\hline \multicolumn{5}{|l|}{ 11. Motivator } \\
\hline a. Parents & 90 & 81.82 & 54 & 81.82 \\
\hline b. Self & 18 & 16.36 & 10 & 15.15 \\
\hline c. Others & 2 & 1.82 & 2 & 3.03 \\
\hline
\end{tabular}

Some experts, such as Amir \& Gati, Osipow, and Tagay, stated that difficulties in deciding on a career are the most frequent academic and vocational problems [3]. Mau found that many students struggle in making career decisions at the higher education level while experiencing a transition from the period of education to the world of work [3]. According to Slaney, career decision difficulty means problems encountered by individuals in deciding their careers [2].

Results showed that the majority of respondents in both groups experienced moderate difficulties in deciding their careers. This result was supported by a study towards 232 students who had different ethnic and racial backgrounds, which found that the majority reported moderate difficulties in deciding their careers and groups of Asian Americans reported higher levels of difficulty than other ethnic or racial groups [4]. This result was also supported by another study towards various ethnicities of high school and university students in America which found that Asian American students perceived significantly more difficulties in 
career decision making than other groups, they reported difficulties before the learning process and more difficulties during the learning process [5]. The moderate difficulties experienced by these study respondents potentially cause by Asian ethnic.

Table 2. Significant differences of career decision difficulty between nursing freshmen and interns

\begin{tabular}{|c|c|c|c|c|c|c|c|c|c|}
\hline \multirow{2}{*}{$\begin{array}{l}\text { Item } \\
\text { Number }\end{array}$} & \multirow[t]{2}{*}{ Statement } & \multirow[t]{2}{*}{ Domain } & \multicolumn{2}{|c|}{$\begin{array}{c}\text { Freshmen } \\
(\mathrm{n}=110)\end{array}$} & \multicolumn{2}{|c|}{$\begin{array}{l}\text { Interns } \\
(\mathrm{n}=66)\end{array}$} & \multirow{2}{*}{$\begin{array}{c}\mathrm{T}- \\
\text { statistic }\end{array}$} & \multirow{2}{*}{$\begin{array}{l}\text { Mean } \\
\text { dif. } \\
\text { (CI95\%) }\end{array}$} & \multirow[t]{2}{*}{$\begin{array}{c}\mathrm{p}- \\
\text { value }\end{array}$} \\
\hline & & & Mean & SD & Mean & SD & & & \\
\hline 5 & $\begin{array}{l}\text { A general need for } \\
\text { confirmation and } \\
\text { support for decisions }\end{array}$ & Indecisiveness & 6.74 & 2.47 & 5.74 & 2.66 & 2.509 & .994 & .013 \\
\hline 9 & $\begin{array}{l}\text { The belief that there is } \\
\text { an ideal career which } \\
\text { can fulfill all aspirations }\end{array}$ & & 6.84 & 1.90 & 6.11 & 2.39 & 2.237 & .730 & .027 \\
\hline 10 & $\begin{array}{l}\text { The belief that a career } \\
\text { choice is a one-time } \\
\text { thing and a life-long } \\
\text { obligation }\end{array}$ & Dysfunctional Myths & 7.29 & 1.79 & 6.18 & 2.40 & 3.486 & 1.109 & .001 \\
\hline 12 & $\begin{array}{l}\text { About the factors to take } \\
\text { into consideration }\end{array}$ & Lack of Knowledge & 4.63 & 2.10 & 3.48 & 2.25 & 3.400 & 1.142 & .001 \\
\hline 13 & $\begin{array}{c}\text { About how to combine } \\
\text { information concerning } \\
\text { the self and career } \\
\text { alternatives }\end{array}$ & $\begin{array}{l}\text { About the Process of } \\
\text { Career Decision } \\
\text { Making }\end{array}$ & 4.61 & 2.17 & 3.81 & 2.63 & 2.158 & .791 & .032 \\
\hline 16 & $\begin{array}{l}\text { Lack of information } \\
\text { about preferred career } \\
\text { alternatives }\end{array}$ & & 4.40 & 2.08 & 3.44 & 2.27 & 2.869 & .961 & .005 \\
\hline 17 & $\begin{array}{l}\text { Lack of information } \\
\text { about career-related } \\
\text { preferences }\end{array}$ & Lack of Information & 4.40 & 2.29 & 3.30 & 2.41 & 3.015 & 1.097 & .003 \\
\hline 18 & $\begin{array}{c}\text { Lack of information } \\
\text { about abilities in the } \\
\text { future }\end{array}$ & Lack or intoritration & 4.67 & 2.40 & 3.67 & 2.39 & 2.697 & 1.006 & .008 \\
\hline 19 & $\begin{array}{l}\text { Lack of information } \\
\text { about personality traits } \\
\text { in the future } \\
\text { Lack of information }\end{array}$ & & 4.51 & 2.41 & 3.65 & 2.43 & 2.274 & .858 & .024 \\
\hline 23 & $\begin{array}{l}\text { about the characteristics } \\
\text { of the career or training } \\
\text { alternatives that interest } \\
\text { the individual }\end{array}$ & $\begin{array}{l}\text { Lack of Information } \\
\text { About Occupations }\end{array}$ & 4.74 & 2.22 & 3.95 & 2.55 & 2.140 & .782 & .034 \\
\hline 24 & $\begin{array}{l}\text { Lack of information } \\
\text { about the variety of } \\
\text { future career or training } \\
\text { alternatives }\end{array}$ & & 4.63 & 2.23 & 3.86 & 2.60 & 2.065 & .764 & .040 \\
\hline 27 & $\begin{array}{c}\text { Lack of information } \\
\text { about ways of obtaining } \\
\text { additional information } \\
\text { about career and training } \\
\text { alternatives }\end{array}$ & $\begin{array}{l}\text { Lack of Information } \\
\text { About Ways of } \\
\text { Obtaining Additional } \\
\text { Information }\end{array}$ & 4.50 & 2.40 & 3.57 & 2.55 & 2.415 & .924 & .017 \\
\hline 35 & $\begin{array}{c}\text { Several equally } \\
\text { attractive career } \\
\text { alternatives } \\
\text { Abilities exceed those }\end{array}$ & Internal Conflicts & 6.82 & 2.01 & 5.50 & 2.50 & 3.833 & 1.318 & .000 \\
\hline 40 & $\begin{array}{l}\text { required in the preferred } \\
\text { career alternative }\end{array}$ & & 5.15 & 1.92 & 4.20 & 2.16 & 3.056 & .958 & .003 \\
\hline Overall & $\begin{array}{l}\text { Career Decision } \\
\text { Difficulties }\end{array}$ & $\begin{array}{l}\text { 1) lack of readiness, 2) } \\
\text { indecisiveness, 3) } \\
\text { dysfunctional myth, 4) } \\
\text { lack of know-ledge } \\
\text { about the process of } \\
\text { career decision making, } \\
\text { 5) lack of information } \\
\text { about self, 6) lack of } \\
\text { information about } \\
\text { occupations, 7) lack of } \\
\text { ways of obtaining } \\
\text { additional infor-mation, } \\
\text { 8) unreliable } \\
\text { information, 9) internal } \\
\text { and external conflicts. }\end{array}$ & 191.32 & 43.38 & 174.39 & 74.06 & 2.563 & 22.830 & .057 \\
\hline
\end{tabular}


According to Mau and Tagay, culture can influence one's career development and career decision making processes [3]. In this study, most respondents are Balinese, but 100\% Asian. Many Asian students choose a college major because of parents and other authority figures. A study towards 375 Taiwanese college students found that their academic commitment to a certain major tend to increase when they choose it based on personal and career preferences which indicate a high level of academic commitment resulted in high levels of career self-efficacy which augments the extent of career-decision readiness [6]. In this study, we found the majority of freshmen $(49.09 \%)$ chose nursing major because of personal dream/preference, while only a small number of interns $(19.70 \%)$ who chose accordingly; but both groups experienced moderate difficulties similarly. Coon (2008) argued that students who have low career self-efficacy and optimism tend to use avoidance coping methods that make it difficult to decide on a career increase; there are also some cognitive variables that influence the difficulty. There was a significant correlation between career decision-making self-efficacy and career decision difficulty in students [4]. Therefore, academic commitment, career self-efficacy, optimism, and cognitive variables in nursing students need to be explored further.

In this study, we found more female students and this is common in nursing major. Difficulties in deciding on a career are not significantly different between male and female students [7]. A study towards 1,006 college students showed that there was insignificant difference between genders in global problem levels in career decision making; women reported more problems with life-goal awareness and authority orientation, while men reported more problems with secondary gain motivations [8]. Therefore although we found most respondents were females in both groups, there was no significant difference of career decision difficulties found between groups. Another study towards 347 Australian high school students from single-gender and coeducational schools found that there was insignificant difference between genders regarding career decidedness, although boys reported higher career knowledge and girls were more motivated and flexible with regard to careers; students at single-gender schools were more undecided than others from coeducational schools [9]. In the context of nursing, similar study is a bit difficult to be conducted due to males are less preferred to choose nursing major, especially in Indonesian context, otherwise multicenter study needs to be conducted to analyze the differences between female and male nursing college students regarding their career decision difficulties.

In this study, freshmen experienced higher difficulties than interns (Mean: 174.39 vs. 191.32). This is potentially influenced by the age differences between groups, in which most of nursing interns were older than the freshmen. A study towards 209 veteran and active students at the University of Midwest, USA; which found that younger respondents turned out to be less prepared so that the difficulty in deciding a career was higher compared to the older students [3]. Another study towards 121 high school students compared to 127 adults found that career decision difficulties was experienced across ages in which adults experienced fewer difficulties compared to younger individuals or students [10]. Different patterns in time perspective resulted in different types of career decision-making difficulties in adults [11]. Freshmen experienced more difficulties than interns also potentially because of low self-efficacy. Another study towards 149 freshmen in Canada found that there was a significant negative correlation between career decision-making difficulties and self-efficacy, which was different between career indecision degrees and whether freshmen had changed their career plans since the beginning of college life or not [12].

Most respondents in both groups are living with their parents whose profession is other than nursing. Family belongingness was significantly related to career decision-making difficulties in undergraduate university students [13]. A study towards 229 college students showed that there was a significant negative association between levels of family cohesion with levels of decision-making confusion, commitment anxiety, and external conflict; levels of family adaptability were negatively associated with levels of external conflict [14]. This study also found that external conflict was not significantly different between groups. There is a high possibility that most respondents experience moderate level of family adaptability and cohesion, so that most of them experienced moderate difficulties in career decision-making. Another study towards 98 new students at a private university in the Midwestern showed that there was a significant relationship between adaptability, emotional intelligence, intrapersonal and interpersonal values, and stress management to difficulties in deciding a career [15].

Overall, there was no significant difference in career decision difficulty between nursing freshmen and interns $(\mathrm{p}=.057)$; especially aspects of lack of readiness and inconsistent information which seemed to be similar in both groups (both $\mathrm{p}>\alpha$ ). Prior to the beginning of learning process in the university, there were three domains of career decision difficulty affected by significant differences between groups (75\%), namely: indecisiveness, dysfunctional myths, and lack of knowledge about the process of career decision making; while during the learning process or study period in the university, there were four domains affected (80\%), namely: lack of information, lack of information about occupations, lack of information about ways

Comparison of career decision difficulties between nursing freshmen and... (Ni Putu Wulan Purnama Sari) 
of obtaining additional information, and internal conflicts (all $\mathrm{p}<\alpha$ ). Lack of information seemed to be the key of significant differences found between groups.

This study results were supported by a study towards 782 university students which found that most respondents were certain about their future career; significant predictors of career uncertainty were found to be: 1) lack of information about the decision-making process, 2) lack of information about occupations, 3) inconsistent information due to internal conflict, 4) exhaustion, 5) lack of information about ways of obtaining information, 6) inconsistent information due to external conflict, 7) cynicism, and 8) lack of dedication [16]. Another study towards university students in Greece also found that factors of lack of information, inconsistent information, and lack of readiness were positively correlated with dysfunctional career thoughts, decision-making confusion, commitment difficulty, and lack of determination; but oppositely, all aforementioned factors were negatively correlated with generalized self-efficacy [17].

Gati, et al. found that lack of readiness cause by lack of motivation, general indecisiveness, and diysfunctional beliefs [2]; motivation was not identified in this study. Results showed that indecisiveness (item 5) and dysfunctional myths/beliefs (item 9 and 10) were significantly different between groups, but lack of readiness was experienced similarly in both groups. Low motivation is potentially being the cause of lack of readiness in both groups. A study towards 496 college students majoring in natural sciences and education showed that lack of motivation acted as asymmetry factor for both the difficulty of making the choice and the certainty about one's decision [18].

Another study towards 222 college students (men and women) showed that there was a significant association between self-concept, career indecisiveness, and identity-related career decision-making difficulties with depression [19]. Depression was not identified in this study, but it potentially influences the career indecisiveness in nursing students. Lipshits-Braziler, et al., proposed three strategies for managing career indecisiveness in college students, namely: productive, support-seeking, and nonproductive coping strategies [20]. Their study towards 251 college students (freshmen) showed that there was a significant positive association between the use of nonproductive coping strategies at the beginning of the preparatory program and the degree of individuals' career decision-making difficulties; therefore the type of coping strategies could predict the individuals' advancement toward making a career decision [20]. Another study towards 364 students showed that career decision-making strategies and resilience contributed $46 \%$ to the variance in career decision difficulty [21].

Dysfunctional myth is thoughts or beliefs that are rather irrational, however influential to individual's decision. A study towards 496 college students majoring in natural sciences and education showed that dysfunctional myths could influence the difficulty of making the choice and the certainty about one's decision [18]. Another study towards 446 Korean college students showed that dysfunctional career thoughts were negatively correlated with vocational identity and career decision self-efficacy, and it was partially mediate the association between both variables [22]. Similar study in nursing students was not found yet. In different population, a study towards 46 adult immigrants showed that dysfunctional career thoughts were significantly and directly related with attachment anxiety and avoidance, but were significantly and indirectly related with decision-making confusion and external conflict [23]. Dysfunctional myth seems to strongly correlate with career decision self-efficacy which potentially being a good predictor of career decision difficulty in university students.

Lack of knowledge about the process of career decision making was significantly different between groups (item 12-13). It is more common to be found in junior college students, especially freshmen. A study towards 496 college students majoring in natural sciences and education showed that factors related to lack of knowledge about career decision-making steps could influence the career decision difficulty and individual's certainty [18].

Results showed that despite of inconsistent information the significant differences found between groups were mostly influenced by lack of information (item 16-19) compared to other domains of career decision difficulty, especially lack of information about occupation (item 23-24) and ways of obtaining additional information (item 27). Lack and inconsistent career information is commonly experienced by undecided college students who reported lower career decision-making self-efficacy with more career decision difficulties and negative career thoughts [24]. A study towards 496 college students majoring in natural sciences and education showed that lack of information (about the various occupations and self) and motivation could influence the career decision difficulty and individual's certainty [18].

A further analysis towards Career Decision Difficulties Questionnaire which compared to Career Decision Scale and Career Factors Inventory showed that there were six reliable factors of career decision problems, namely: lack of information, need for information, trait indecision, disagreement with others, identity diffusion, and choice anxiety. From these six factors, three factors were being the structure of the indecision domains, namely: information deficit/identity diffusion, decision process inhibitors, and choice inhibitors [25]. This analysis results supported this study result which found that among all domains of career 
decision difficulties reported by Career Decision Difficulties Questionnaire, lack of information being the most affected domains between groups; it was foundational domains of career decision difficulties requiring special attention and treatment from academic advisor and counselor or psychologist.

Conflicts may arise in every individual. In this study, we found that external conflicts happened similarly in both groups, but internal conflicts were significantly different between groups (item 35 and 40). Internal conflict could cause inconsistent information which is being one of the significant predictors of career uncertainty in university students [16], and this inconsistent information could develop dysfunctional career thoughts, decision-making confusion, commitment difficulty, and lack of determination [17]. Therefore, academic advisor needs to be cautious about internal conflicts in university students because it could be one of the root-cause of career decision difficulties encounter by the students afterwards.

In general, the results of this study showed that moderate difficulties were found in nursing freshmen and interns, especially aspects of lack of readiness and inconsistent information were found to be similar in both groups, regardless the influence of age, sex, and culture. There was no significant difference of career decision difficulty found between groups indicated that future career decisions for university students are still being something that is relatively difficult to decide on their own. Therefore, the involvement and support from parents, lecturers, academic advisor, and peers are important contributions in the career decision making process. Counseling during the study period in the university should be given to students who in need, and if necessary their parents need to be presented in the meeting in order to match the career expectations between both parties so that the future career/profession can be decided together.

\section{CONCLUSION}

Most nursing freshmen and interns experienced moderate difficulties in deciding their future career. Overall, there is no significant difference in career decision difficulty between nursing freshmen and interns, especially in aspects of lack of readiness and inconsistent information. However, more career decision difficulties were found in nursing freshmen compared to interns, which influenced by indecisiveness, dysfunctional myths, lack of knowledge about the process of career decision making, lack of information, lack of information about occupations, lack of information about ways of obtaining additional information, and internal conflicts. Specific intervention in the higher education level targeting modification of these aspects in the beginning or during the study period in the university potentially leads to the decrease of career decision difficulty encountered by nursing students.

\section{ACKNOWLEDGEMENTS}

This study was funded and supported for publication by Faculty of Nursing, Widya Mandala Catholic University Surabaya.

\section{REFERENCES}

[1] P. Creed, M. Hood, O Wong, "Career Decision-Making, Career Barriers and Occupational Aspirations in Chinese Adolescents," International Journal for Educational and Vocational Guidance, vol.9, no.3, pp.189-203, 2009.

[2] I. Gati, M. Krausz, S. H. Osipow, S. "A Taxonomy of Difficulties in Career Decision Making," Journal of Counseling Psychology, vol.43, no.4, pp.510-526, 1996.

[3] L. M. Laveck, "Career Decision-making Difficulties among Student Veterans," Dissertation, ProQuest Dissertations Publishing, 11005236, 2018.

[4] G. Feinstein-Messinger, "The Nexus among Career Decision Self-efficacy, Parental Relationship Factors, and Career Indecision among College Students from Different Ethnic and Racial Groups," Dissertation, ProQuest Dissertations Publishing, 3245030, 2007.

[5] W. C. J. Mau, "Cultural Dimensions of Career Decision-Making Difficulties," The Career Development Quarterly, vol.53, no.1, pp.67-77, 2004.

[6] C. N. Liao, C. H. Ji, "The Origin of Major Choice, Academic Commitment, and Career-Decision Readiness among Taiwanese College Students," The Career Development Quarterly, vol.63, pp.156-170, 2015.

[7] L. C. Farrar, "Relationships between Vocational Decision-making Styles and Career Decision-making Difficulties of Low Socio-Economic Status High School Students in Residential Education," Dissertation, ProQuest Dissertations Publishing, 3357200, 2009.

[8] J. H. Larson, M. Butler, S. Wilson, N. Medora, S. Aligood, "The Effects of Gender on Career Decision Problems in Young Adults," Journal of Counseling \& Development, vol.3, no.1, pp.79-84, 1994.

[9] M. J. Albion, "Career Decision Making Difficulties of Adolescent Boys and Girls," Australian Journal of Career Development, vol.9, no.2, pp.14-19, 2000.

[10] M. J. Albion, G. J. Fogarty, "Factors Influencing Career Decision Making in Adolescents and Adults," Journal of Career Assessment, vol.10, no.1, pp.91-126, 2002.

Comparison of career decision difficulties between nursing freshmen and... (Ni Putu Wulan Purnama Sari) 
[11] B. J. Taber, "Time Perspective and Career Decision-making Difficulties in Adults," Journal of Career Assessment, vol.21, no.2, pp.200-209, 2013.

[12] T. Morgan, D. Ness, "Career Decision-Making Difficulties of First-Year Students," 2003. Retrieved from: http://cjcdonline.ca/wp-content/uploads/2014/11/Career-Decision-Making-Difficulties-of.pdf

[13] C. D. Slaten, T. W. Baskin, "Examining the Impact of Peer and Family Belongingness on the Career Decisionmaking Difficulties of Young Adults: A Path Analytic Approach," Journal of Career Assessment, vol.22, no.1, pp.59-74, 2013.

[14] D. Lustig, Y. Xu, "Family-of-Origin Influence on Career Thoughts," The Career Development Quarterly, vol.66, pp.149-161, 2018.

[15] D. Wiljanen, "Emotional Intelligence, Career Decision Difficulties, and Student Retention: A Quantitative Study," Dissertation, ProQuest Dissertations Publishing, 3549113, 2012.

[16] H. Botha, K. Mostert, "Significant Predictors Associated with The Career Uncertainty of University Students," South African Journal of Higher Education, vol.27, no.3, pp.501-521, 2013.

[17] D. Sidiropoulou-Dimakakou, K. Mylonas, K. Argyropoulou, S. Tampouri, "Career Decision-making Difficulties, Dysfunctional Thinking and Generalized Self-efficacy of University Students in Greece," World Journal of Education, vol.2, no.1, pp.117-130, 2012.

[18] D. Stamovlasis, J. Vaiopoulou, "The Role of Dysfunctional Myths in A Decision-Making Process Under Bounded Rationality: A Complex Dynamical Systems Perspective," Nonlinear Dynamics, Psychology, and Life Sciences, vol.21, no.3, pp.267-288, 2017.

[19] R. Gadassi, A. Wasser, I. Gati, "Gender Differences in the Association of Depression with Career Indecisiveness, Career-decision Status, and Career-preference Crystallization,” Journal of Counseling Psychology, vol.62, no.4, pp.632-41, 2015.

[20] Y. Lipshits-Braziler, I. Gati, M. Tatar, "Strategies for Coping with Career Indecision: Concurrent and Predictive Validity," Journal of Vocational Behavior, vol.91, pp.170-179, 2015.

[21] Y. J. Shin, K. R. Kelly, "Resilience and Decision-making Strategies as Predictors of Career Decision Difficulties," The Career Development Quarterly, vol.63, no.4, pp.291-305, 2015.

[22] H. Jo, Y. A. Ra, J. Lee, W. H. Kim, "Impact of Dysfunctional Career Thoughts on Career Decision Self-efficacy and Vocational Identity," The Career Development Quarterly, vol.64, pp.333-344, 2016.

[23] Y. van Ecke, "Attachment Style and Dysfunctional Career Thoughts: How Attachment Style Can Affect the Career Counseling Process," The Career Development Quarterly, vol.55, pp.339-350, 2007.

[24] E. Bullock-Yowell, A. E. Mc. Connell, E. A. Schedin, "Decided and Undecided Students: Career Self-efficacy, Negative Thinking, and Decision-Making Difficulties," NACADA Journal, vol.34, no.1, pp.22-34, 2014.

[25] K. R. Kelly, W. C. Lee, "Mapping the Domain of Career Decision Problems," Journal of Vocational Behavior, vol.61, no.2, pp.302-326, 2002. 